\title{
IMPLEMENTASI PENGELOLAAN KEUANGAN DESA TAHUN ANGGARAN 20 I 9 DI DESA BAAMPAH KECAMATAN MENTAYA HULU
}

\author{
IMPLEMENTATION ON VILLAGE FINANCIAL MANAGEMENT OF 2019 \\ IN BAAMPAH VILLAGE, MENTAYA HULU SUB-DISTRICT
}

\section{Sugoro Daru Pradibyo}

Universitas Terbuka

email:

sugorol/sugoro@gmail.com

\section{Kata Kunci:}

Implementasi

Keuangan

Desa

\section{Keywords:}

Implementation

Village

Finance

\begin{abstract}
Abstrak
Undang-Undang Nomor 6 Tahun 2014 tentang Desa memberikan semangat baru bagi desa untuk bangkit baik dari segi pembangunan, perekonomian dan kesejahteraan masyarakatnya. Lahirnya UU tersebut telah membuka peluang bagi desa untuk mengelola anggaran yang cukup besar baik yang bersumber dari pusat (DD), Pemerintah Daerah (ADD, DBH Pajak dan Retribusi Daerah) dan Pendapatan Asli Desa itu sendiri. Pengelolaan keuangan desa menjadi satu hal yang harus menjadi perhatian karena anggaran tersebut harus dikelola dengan transparan dan akuntabel sesuai dengan asas pengelolaan keuangan desa. Arahan baik berupa pembinaan dan pengawasan dari pihak kecamatan dan kabupaten menjadi faktor yang sangat penting sehingga Kepala Desa selaku penanggungjawab pengelolaan keuangan desa bertindak sesuai dengan kewenagan yang diberikan dan ketentuan yang mengaturnya mulai dari tahap perencanaan, pelaksanaan, penatausahaan, pelaporan dan pertanggungjawaban. Pemerintah Kabupaten Kotawaringin Timur telah menetapkan Peraturan Bupati Nomor 4 Tahun 2019 tentang Pengelolaan Keuangan Desa sebagai turunan dari Peraturan Menteri Dalam Negeri Nomor 20 Tahun 2018, hal tersebut sebagai pedoman dan memberikan kemudahan bagi desa dalam hal mengelola anggaran.
\end{abstract}

\begin{abstract}
Law of the Republic of Indonesia Number 6 Year of 2014 on village encourages the development, economy, and prosperity of the people. The enactment of the law crates opportunities for villages to manage the significant amount of budget from central (DD), Local Government (ADD, DBH tax and regional retribution) and locally generated revenue of the village itself. Financial management should be taken into consideration as it should be transparent and accountable following management principle of village finance. Briefing including coaching and supervision from both sub-district and district levels plays significant factor, so the Headman as the responsible one proceeds by complying the given power and governing provisions in planning, performing, administering, reporting, and accountability. East Kotawaringin District Government enacted Mayor Regulation Number 4 Year of 2019 on Village Financial Management as the derivative of the Regulation of Minister of Internal Affairs Republic of Indonesia Number 20 Year of 2018, as guidance that simplifies village in managing the budget.
\end{abstract}




\section{PENDAHULUAN}

Terbitnya Undang-Undang Nomor 6 Tahun 2014 tentang Desa merupakan titik tolak bangkitnya pembangunan desa, dengan harapan desa mampu mengejar atau memperkecil ketertinggalan baik dari segi pembangunan serta pertumbuhan ekonomi. UndangUndang No.6 membuka peluang bagi desa untuk dapat mengelola dana yang cukup besar, baik yang bersumber dari Bantuan Keuangan dari Pemerintah Pusat yang disebut Dana Desa (DD), desa juga memperoleh Bantuan Dana dari Pemerintah Daerah yang disebut Alokasi Dana Desa (ADD), dan masih ada beberapa sumber-sumber pendanaan lain yang masuk ke desa baik diantaranya Dana Bagi Hasil Pajak Daerah dan juga Dana Bagi Hasil Retribusi Daerah yang memberikan kesempatan bagi desa untuk mengelola sendiri dana yang diterima yang jumlahnya cukup besar untuk membiayai program dan kegiatan didesa.

Semenjak implementasi Undang-Undang Nomor 6 Tahun 2014, Dana Bantuan Keuangan yang bersumber dari Pemerintah Pusat dari tahun ke tahun mengalami peningkatan yang signifikan, dimana Pemerintah Pusat penargetkan setidaknya masing-masing desa akan mendapatkan dana setidaknya I Miliar rupiah. Percepatan pembangunan desa melalui anggaran yang diberikan oleh pemerintah, desa juga diberikan kewenangan untuk menggali potensi yang dimiliki oleh desa baik dari kondisi kekayaan alamnya, topograsi dan demograsi yang ada didesa. Desa diharapkan mampu mandiri dengan menggali potensi tersebut untuk memperoleh pendapatan sebesar-besarnya yang menjadi Pendapatan Asli Desa, dimana dana yang dikelola tersebut akan dikelola sendiri dengan asas pola keuangan desa yaitu transparan, akuntabel, partisipatif serta dilakukan dengan tertib dan disiplin anggaran.

Dalam mendukung implementasi Undang-Undang Nomor 6 Tahun 2014 tentang Desa, yang dijabarkan dalam Peraturan Pemerintah Republik Indonesia Nomor 43 tentang Peraturan Pelaksanaan UndangUndang Nomor 6 Tahun 2014 Tentang Desa.
Perbaikan-perbaikan standar Pedoman Pengelolaan Keuangan Desa pun terus dilakukan oleh Pemerintah Pusat, yang awal diatur dalam Peraturan Menteri Dalam Negeri Republik Indonesia Nomor II3 Tahun 2014, kemudian diperbaharui dengan Peraturan Menteri Dalam Negeri Republik Indonesia Nomor 20 Tahun 2018 tentang Pengelolaan Keuangan Desa. Pemerintah Daerah Kabupaten Kotawaringin Timur juga berupaya memberikan kemudahan bagi desa dalam hal mengelola keuangan desa yaitu dengan membuat dan menetapkan Peraturan Bupati Nomor 4 Tahun 2019 tentang Pengelolaaan Keuangan Desa.

Implementasi pengelolaan keuangan desa berdasarkan Perbup Nomor 4 Tahun 2019 Pasal 44 yang berbunyi bahwa "Pengelolaan keuangan desa meliputi : a. perencanaan; b. pelaksanaan; c. penatausahaan; d. pelaporan; dan e. Pertanggungjawaban." keuangan desa merupakan rangkaian tahapan yang saling berkaitan antara satu dengan yang lain.

Edward III dalam Erwan dan Diah (2015:85) mengidentifikasikan ada empat critical factors yang mempengaruhi keberhasilan proses implementasi. Keempat faktor tersebut adalah komunikasi, sumberdaya, disposisi atau perilaku dan struktur birokrasi.

Struktur organisasi; merupakan salah-satu institusi yang paling sering bahkan secara keseluruhan menjadi pelaksana kegiatan. Keberadaan birokrasi tidak hanya dalam struktur pemerintah, tetapi juga ada dalam organisasi-organisasi swasta, institusi pendidikan dan sebagainya. Bahkan dalam kasus-kasus tertentu birokrasi diciptakan hanya untuk menjalankan suatu kebijakan tertentu. Terdapat dua karakteristik utama dari birokrasi yakni: "Standard Operational Procedure (SOP) dan fragmentasi".

Sumberdaya; merupakan hal penting dalam implementasi kebijakan yang baik. Indikator-indikator yang digunakan untuk melihat sejauhmana sumberdaya mempengaruhi implementasi kebijakan terdiri dari : staf; informasi; wewenang; dan fasilitas. 
Disposisi atau perilaku; Kecenderungan-kecenderungan atau disposisi merupakan salah-satu faktor yang mempunyai konsekuensi penting bagi implementasi kebijakan yang efektif. Jika para pelaksana mempunyai kecenderungan atau sikap positif atau adanya dukungan terhadap implementasi kebijakan maka terdapat kemungkinan yang besar implementasi kebijakan akan terlaksana sesuai dengan keputusan awal. Demikian sebaliknya, jika para pelaksana bersikap negatif atau menolak terhadap implementasi kebijakan karena konflik kepentingan maka implementasi kebijakan akan menghadapi kendala yang serius. Faktor-faktor yang menjadi perhatian Edward III mengenai disposisi dalam implementasi kebijakan terdiri dari : pengangkatan birokrasi; dan insentif.

Komunikasi; Implementasi yang efektif akan terlaksana, jika para pembuat keputusan mengetahui mengenai apa yang akan mereka kerjakan. Infromasi yang diketahui para pengambil keputusan hanya bisa didapat melalui komunikasi yang baik. Terdapat tiga indikator yang dapat digunakan dalam mengkur keberhasilan variabel komunikasi. Edward III dalam Agustino (2006:157-I58) mengemukakan tiga variabel tersebut yaitu : trasmisi; kejelasan; dan konsistensi.

Pengelolaan Keuangan Desa yang menggambarkan keseluruhan kegiatan yang meliputi perencanaan, pelaksanaan, penatausahaan, pelaporan, dan pertanggungjawaban keuangan desa merupakan rangkaian tahapan yang saling berkaitan antara satu dengan yang lain. Dimulai dari tahapan perencanaan yaitu Musyawarah Desa (Musdes) yang ditetapkan dengan Rencana Kerja Pemerintah Desa (RKPDesa), kemudian dari RKPDesa dijadikan dasar dalam penyusunan Anggaran Pendapatan dan Belanja Desa (APBDesa) yang disesuaikan dengan besaran Pendapatan yang diperhitungkan baik dari Dana Desa (DD) dari Pemerintah Pusat, Alokasi Dana Desa (ADD), Dana Bagi Hasil Pajak dan Retribusi Daerah yang berasal dari Pemerintah Kabupaten, juga estimasi perhitungan Pendapatan Asli Desa yang digunakan untuk membiayai
Belanja dan Pembiayaan Desa. APBDesa yang dituangkan dalan Peraturan Desa merupakan pegangan yang digunakan oleh Pemerintahan Desa dalam tahap pelaksanaan, penatausahaan, pelaporan dan pertanggungjawaban pada tahun anggaran berjalan yakni mulai tanggal I Januari sampai dengan tanggal 3 I Desember.

Terdapat beberapa penelitian terkait pengelolaan keuangan desa diantaranya Vica Mayela Laurentya yang melakukan penelitian dengan judul "Akuntabilitas Implementasi Pengelolaan Alokasi Dana APBDesa dan Implikasinya Terhadap Kesejahteraan Masyarakat (di Desa Pademonegoro Kecamatan Sukoharjo Kabupaten Sidoarjo)" dan Fadhil Azhar melakukan penelitian dengan judul "Akuntabilitas Pengelolaan Dana Desa (Studi Kasus di Desa Uekuli Kecamatan Tojo Kabupaten Tojo Una-Una)". Pada penelitian terdahulu pengelolaan keuangan desa masih menggunakan Permendagri No.I I3 Tahun 2014. Dari penelitian tersebut diketahui bahwa pengelolaan keuangan desa sudah berjalan dengan baik namun masih terdapat kendala seperti keterlambatan informasi pagu anggaran desa sehingga menyebabkan penetapan Perdes tentang APBDes terlambat.

\section{METODOLOGI}

Metode penelitian yang digunakan dalam penelitian ini adalah penelitian kualitatif. Pendekatan kualitatif ini digunakan dalam rangka mendapatkan data deskriptif berupa kata-kata tertulis dari orang atau sample yang digunakan sebagai responden penelitian (Siti Muntahanah, 2014:4). Menurut Sugiyono (2010:9), metode penelitian kualitatif adalah metode penelitian yang berlandaskan pada filsafat postpositivisme, digunakan untuk meneliti pada kondisi obyek yang alamiah, (sebagai lawannya adalah eksperimen) dimana peneliti adalah sebagai instrumen kunci, teknik pengumpulan data dilakukan secara triangulasi (gabungan), analisis data bersifat induktif/kualitatif, dan 
hasil penelitian kualitatif lebih menekankan makna dari pada generalisasi.

Sumber data primer untuk penelitian kualitatif ini adalah informan.

Data primer adalah data yang diperoleh langsung dari responden atau informan atau diperoleh dari pengamatan terhadap suatu kegiatan dan tempat tertentu. Informan adalah orang yang dipandang mempunyai pengetahuan atau informasi mengenai suatu hal atau peristiwa tertentu, atau dengan kata lain informasi-informasi yang diperoleh dari pelaku kegiatan. Kualifikasi terkait informasi dimiliki oleh yang bersangkutan, baik karena kedudukannya sebagai orang yang berwenang pada jabatan tertentu maupun karena kegiatannya dalam proses dibidang tertentu.

Data sekunder adalah data yang diperoleh dari dokumen yang telah disahkan atau telah dipublikasikan. Oleh karena itu, dalam penelitian ini sumber data sekunder adalah informasi, data, produk hukum yang dijadikan data dalam penelitian ini.

Menurut Arikunto (2002 : 107) yang dimaksud dengan sumber data adalah "Subyek darimana data dapat diperoleh". Penulis dapat mengkasifikasikan sumber data mengacu pada pendapat Arikunto (2002 : 107), yaitu :

I. Person, yaitu sumber data berupa orang yang dapat memberikan data berupa jawaban lisan melalui wawancara dan jawaban tertulis melalui angket. Pada penelitian ini sumber person yang diambil oleh peneliti adalah Kepala Desa, Ketua BPD, Sekretaris Desa, Bendahara Desa, Tim Pelaksana Kegiatan, Pegawai Kecamatan, Pegawai DPMD Kabupaten Kotawaringin Timur dan sumber lainnya.

2. Paper, yaitu sumber data yang menyajikan tandatanda berupa huruf, angka, gambar atau simbol-simbol lain. Data yang bersumber dari paper adalah data-data penunjang diperoleh dari buku-buku, dokumendokumen dan arsip-arsip. Pada penelitian ini paper yang yang diperoleh peneliti adalah RPJMDes, RKPDes,
APBDes, LPJ APBDes, Dokumen permohonan pencairan APBDes, SPJ Desa dan dokumen lain.

Menurut Nazir (2009 : 174) "Pengumpulan data adalah prosedur yang sistematis dan standar untuk memperoleh data yang diperlukan". Untuk dapat memperoleh data yang diperlukan dalam penelitian ini, penulis menggunakan teknik pengumpulan data wawancara, observasi dan dokumentasi.

Miles and Huberman dalam Sugiyono (2013: 246) mengemukakan bahwa aktivitas dalam analisis data kualitatif dilakukan secara interaktif dan berlangsung secara terus menerus sampai tuntas, sehingga datanya sudah jenuh. Aktivitas dalam analisis data, yaitu data reduction, data display, dan conclusion drawing/verification.

\section{HASIL DAN PEMBAHASAN}

\section{Analisis Pengelolaan Keuangan Desa Baampah}

Tahun Anggaran 2019 Berdasarkan Peraturan Bupati Nomor 4 Tahun 2019

Sesuai dengan Peraturan Bupati Nomor 4 Tahun 2019 pengelolaan keuangan desa meliputi perencanaan, pelaksanaan, penatausahaan, pelaporan dan pertanggungjawaban, diperoleh hasil sebagai berikut :

Tahap Perencanaan, Perencanaan pengelolaan keuangan desa merupakan perencanaan penerimaan dan pengeluaran pemerintahan desa pada tahun anggaran berkenaan yang dianggarkan dalam APBDesa. Perencanaan pengelolaan keuangan desa erat hubungannya dengan perencanaan pembangunan desa.

Hasil wawancara dengan Sekretaris Desa Baampah Bpk. Akhmad Kusasi bahwa :

“Dukumen RKPDes digunakan oleh Pemerintah Desa sebagai dasar dalam penyusunan RAPBDes, kemudian hasil penyusunan RAPBDes yang dikoordinir oleh Sekdes diserahkan kepada Kepala Desa dan kemudian Kepala Desa menyerahkan ke BPD yang pada akhirnya bersama-sama dengan BPD membahas dan menetapkan Peraturan Desa tentang APBDes. Dokumen APBDes tersebut akan menjadi dasar pelaksanaan program dan kegiatan pembangunan oleh pemerintah desa. 
Penatapan Perdes APBDes tersebut biasanya pada awal tahun berjalan, yaitu pada bulan Januari atau Pebruari. Hal ini disebabkan karena lambatnya informasi pagu indikatif DD dan ADD dari pemerintah kabupaten, dalam hal ini Badan Pemberdayaan Masyarakat dan Desa (BPMD) Kabupaten Kotawaringin Timur."

Berdasarkan hasil wawancara dan analisis dengan menggunakan indikator perencanaan yang telah dilakukan diketahui bahwa perencanaan Anggaran Pendapatan dan Belanja Desa (APBDes) Tahun Anggaran 2019 Desa Baampah Kecamatan Mentaya Hulu secara prosedur telah sesuai dengan ketentuan Peraturan Bupati Nomor 4 Tahun 2019 tentang Pengelolaan Keuangan Desa. Namun secara target waktu perencanaan keuangan desa Baampah tidak sesuai dengan waktu yang telah ditetapkan peraturan perundang-undangan, dimana Perdes tentang APBDes TA 2019 baru ditetapkan pada tanggal II Januari 2019.

Dimana partisipatif menurut Krina dalam Ahmad Zaini dan Endang Surasetyo Ningsih (2018) adalah prinsip bahwa setiap orang atau masyarakat memiliki hak untuk terlibat dalam pengambilan keputusan di setiap kegiatan penyelenggaraan pemerintah, hak dalam pengambilan keputusan dapat dilakukan secara langsung atau secara tidak langsung. Dalam hal ini setiap kepala desa harus melibatkan masyarakat dalam proses pengambilan keputusan, APBDesa yang telah disusun/direncanakan oleh perangkat desa harus dimusyawarahkan kembali oleh kepala desa dalam forum yang melibatkan masyarakat secara langsung atau melalui perwakilannya yaitu BPD (Badan Permusyawaratan Desa) sebelum ditetapkan oleh kepala desa. Pengelolaan keuangan desa yang dituangkan dalam APBDesa dikelola dalam masa I tahun anggaran yakni mulai tanggal I Januari sampai dengan 3I Desember.

Keterlambatan penetapan APBDes tersebut akan memberi dampak negatif terhadap jalannya pelaksanaan program dan kegiatan desa sehingga waktu pelaksanaan anggaran tidak dapat berjalan dengan optimal, dimana keuangan desa seharusnya dikelola berdasarkan asas- asas transparan, akuntabel, partisipatif serta dilakukan dengan tertib dan disiplin anggaran. Pengelolaan keuangan desa sesuai dengan ketentuan dikelola dalam masa I (satu) tahun anggaran yakni mulai tanggal I Januari sampai dengan tanggal 3 I Desember.

Tahap Pelaksanaan, Menurut Mardiasmo dalam I Wayan Purwa Astawa (2019), sebagian besar dari anggaran desa merupakan discretionary cost maka pengelolaan keuangan desa harus mampu dikendalikan untuk menghasilkan rencana penganggaran sektor publik yang efektif, efisien dan ekonomis.

Hasil wawancara dengan Bendahara Desa Baampah, yakni :

“Desa Baampah hanya memiliki satu rekening desa atas nama pemerintah desa baampah yang ada pada Bank Pembangunan Kalteng. Seluruh penerimaan dan pengeluaran desa harus melalui rekening desa, baik itu pendapatan transfer DD dan ADD, serta Pendapatan Asli Desa yang menjadi penerimaan desa. Bendahara desa juga paling banyak menyimpan uang sebesar Rp. 50.000.000,- $\mathrm{Hal}$ tersebut dilakukan untuk mempermudah kontrol dan pengawasan keuangan desa. "

Berdasarkan hasil wawancara dan analisis dengan menggunakan indikator pelaksanaan yang telah dilakukan diketahui bahwa pelaksanaan Anggaran Pendapatan dan Belanja Desa (APBDes) Tahun Anggaran 2019 Desa Baampah Kecamatan Mentaya Hulu secara prosedur belum sesuai dengan ketentuan Peraturan Bupati Nomor 4 Tahun 2019 tentang Pengelolaan Keuangan Desa.

Hal ini dapat terlihat dari belum adanya DPA yang disusun oleh Kasi / Kaur yang telah diverifikasi oleh Sekretaris Desa dan disetujui oleh Kepala Desa. Dalam hal usulan pencairan dana, salinan kelengkapan pencairan dana tidak disampaikan ke APIP / Inspektorat Kabupaten, hal ini menyebabkan kurangnya pengawasan terhadap pengelolaan keuangan desa. Selain itu, dalam hal proses pencairan dana, hendaknya pemerintah desa dalam membuat usulan SPP Pencairan Dana agar diperhitungkan dengan lebih baik dan disesuaikan 
dengan kebutuhan sehingga pada saat penutupan kas pada akhir bulan, bendahara desa tidak menyimpan dana melebihi ketentuan yaitu paling banyak Rp.50.000.000,00.

Hal tersebut sesuai dengan pendapat Mardiasmo dalam I Wayan Purwa Astawa (2019), sebagian besar dari anggaran desa merupakan discretionary cost maka pengelolaan keuangan desa harus mampu dikendalikan untuk menghasilkan rencana penganggaran sektor publik yang efektif, efisien dan ekonomis.

Tahap Penatausahaan; Hamzah dalam Iwayan Purwa Astawa (2019), Penatausahaan Keuangan merupakan bagian yang tak terpisahkan dari proses Pengelolaan Keuangan Desa, pelaksanaan penatausahaan keuangan dalam pemerintahan desa harus menetapkan bendahara desa, penetapan bendahara desa harus dilakukan sebelum dimulainya tahun anggaran bersangkutan dan berdasarkan keputusan kepala desa. Kepala desa dalam melaksanakan penatausahaan keuangan desa harus menetapkan bendahara desa. Penetapan bendahara desa harus dilakukan sebelum dimulainya tahun anggaran bersangkutan, Bendahara adalah perangkat desa yang ditunjuk oleh kepala desa untuk menerima, menyimpan, menyetorkan, menatausahakan, membayar dan mempertanggungjawabkan keuangan desa dalam rangka pelaksanaan APBDes.

Penatausahaan keuangan desa merupakan segala penerimaan dan pengeluaran yang ada didesa harus dicatat dengan jelas oleh bendahara desa atas transaksitransaksi yang terjadi serta melakukan tutup buku setiap akhir bulan secara tertib. Bendahara desa wajib mempertanggungjawabkan uang baik penerimaan maupun pengeluaran yang menjadi tanggungjawabnya melalui laporan pertanggungjawaban kepada Kepala Desa paling lambat tanggal 10 bulan berikutnya.

Hal ini sesuai dengan apa yang disampaikan oleh Kepala Desa Baampah, yaitu sebagai berikut.

"penatausahaan keuangan di desa baampah dilakukan oleh bendahara desa yang juga kaur keuangan. Segala bentuk penatausahaan baik penerimaan dan pengeluaran desa harus dicatat oleh bendahara desa pada buku kas umum."

Pernyataan serupa juga diterangkan oleh bendahara desa baampah, yakni :

"bendahara desa wajib mempertanggungjawabkan penerimaan dan pengeluaran desa kepada kepala desa paling lambat tanggal 10 bulan berikutnya. Laporan tersebut setidaknya menggunakan buku kas umum, buku pajak dan buku bank."

Dari indikator yang digunakan untuk menganalisis penatausahaan pengelolaan keuangan desa di Desa Baampah terhadap penerapan Peraturan Bupati Nomor 4 Tahun 2019 tentang Pengelolaan Keuangan Desa, dapat terlihat bahwa Desa Baampah telah melaksanakan penatausahaan dengan cukup baik, namun ketiadaan DPA dan RAK yang seharusnya disusun oleh Kasi dan / atau Kaur menyebabkan pergerakan arus kas didesa kurang termonitor dengan baik, tidak adanya verifikasi Sekdes dalam laporan Buku Kas Umum desa juga tidak sesuai dengan prosedur penyusunan laporan penatausahaan. Selain itu, dalam hal penatausahaan keuangan pihak desa tidak diwajibkan menyampaikan laporan SPJ secara berkala atau setiap bulan kepihak instansi pembina, baik itu Camat, BPKAD / DPMD ataupun Inspektorat sehingga menyebabkan pembinaan dan pengawasan terhadap pemerintahan desa terutama dalam hal pengelolaan keuangan desa dianggap masih kurang optimal.

Hal tersebut sesuai dengan pernyataan Hamzah dalam I Wayan Purwa Astawa (2019), Penatausahaan Keuangan merupakan bagian yang tak terpisahkan dari proses Pengelolaan Keuangan Desa. Kepala desa dalam melaksanakan penatausahaan keuangan desa harus menetapkan bendahara desa. Penetapan bendahara desa harus dilakukan sebelum dimulainya tahun anggaran bersangkutan, Bendahara adalah perangkat desa yang ditunjuk oleh kepala desa untuk menerima, menyimpan, menyetorkan, menatausahakan, membayar dan 
mempertanggungjawabkan keuangan desa dalam rangka pelaksanaan APBDes.

Tahap Pelaporan, Ayi Sumarna (2015) menjelaskan bahwa Pelaporan merupakan salah satu mekanisme untuk mewujudkan dan menjamin akuntabiltas pengelolaan keuangan desa, sebagaimana ditegaskan dalam asas Pengelolaan Keuangan Desa (Asas Akuntabel). Hakikat dari pelaporan ini adalah Pengelolaan Keuangan Desa dapat dipertanggungjawabkan dari berbagai aspek: hukum, administrasi, maupun moral. Dengan demikian, pelaporan pengelolaan keuangan desa menjadi kewajiban Pemerintah Desa sebagai bagian tak terpisahkan dari penyelengaraan pemerintahan desa.

Laporan semester pertama yaitu laporan pelaksanaan kegiatan untuk 6 (enam) bulan yaitu januari sampai dengan juni tahun berjalan, dan laporan tersebut disampaikan paling lambat pada akhir bulan juli tahun berjalan. Sedangkan laporan semester akhir tahun merupakan laporan pelaksanaan kegiatan selama I tahun, yaitu mulai januari sampai desember tahun berjalan, dan laporan akhir tahun tersebut disampaikan paling lambat akhir bulan januari tahun berikutnya. Hal ini sesuai dengan apa yang disampaikan oleh Kepala Desa Baampah.

"pemerintah desa menyampaikan laporan realisasi pelaksanaan APBDes berupa laporan semester pertama yaitu paling lambat bulan juli dan laporan semester akhir tahun yang disampaikan paling lambat akhir bulan januari Kepada Bupati melalui Camat”

Namun berdasarkan wawancara yang dilakukan penulis kepada Bapak Ajid selaku Kepala Bidang Pembangunan dan Keuangan Desa DPMD Kabupaten Kotawaringin Timur diperoleh informasi sebagai berikut.

"dalam hal pemenuhan penyampaian laporan semester pertama dan laporan semester akhir tahun, pemerintah desa sering melakukan keterlambatan penyampaian ke DPMD dengan alasan masih dalam proses pelaksanaan kegiatan dan juga perangkat desa masing mengalami kebingungan dalam menyusun laporan. Proses penyampaian laporan ada yang dilakukan kolektif oleh kecamatan, namun kebanyakan pemerintah desa menyampaikannya secara langsung."

Berdasarkan hasil wawancara, observasi dan dokumentasi yang diperoleh penulis terkait indikator yang digunakan untuk menganalisis pelaporan pengelolaan keuangan desa di Desa Baampah terhadap penerapan Peraturan Bupati Nomor 4 Tahun 2019 tentang Pedoman Pengelolaan Keuangan Desa, dapat terlihat bahwa Desa Baampah telah melaksanakan pelaporan dengan cukup baik, namun masih mengalami keterlambatan penyampaian baik laporan semester pertama maupun laporan akhir tahun. Dari dokumen yang diperoleh penulis diketahui bahwa Laporan realisasi akhir tahun 2019 Desa Baampah baru selesai disusun pada tanggal 9 Pebruari 2020. Hal yang menyebabkan keterlambatan penyusunan dan penyampaian laporan disebabkan kurangnya pemahaman dari aparatur pemerintah desa dalam hal penyusunan dan pentingnya penyampaian laporan secara tepat waktu sesuai dengan ketentuan.

Tahap Pertanggungjawaban, Ayi Sumarna (2015) Sejalan dengan prinsip transparansi, akuntabel, dan partisipatif yang merupakan ciri dasar tata kelola pemerintahan yang baik (Good Governance), maka pertanggungjawaban tidak hanya disampaikan kepada pemerintah yang berwenang, tetapi juga harus disampaikan kepada masyarakat, baik langsung maupun tidak langsung. Secara langsung, pertanggungjawaban kepada masyarakat bisa disampaikan melalui Musyawarah Desa sebagai forum untuk membahas halhal strategis, yang dihadiri BPD dan unsur-unsur masyarakat lainnya. Selain itu, laporan pertanggungjawaban juga dapat disebarluaskan melalui berbagai sarana komunikasi dan informasi: papan Informasi Desa, website resmi pemerintah kabupaten atau bahkan desa.

Hal ini sesuai dengan apa yang disampaikan oleh Kepala Desa Baampah. 
"Pemerintah Desa Baampah setiap tahun menyampaikan laporan pertanggungjawaban realisasi APBDes ke Bupati melalui Camat dalam bentuk Peraturan Desa. Dalam Perdes pertanggungjawaban realisasi pelaksanaan APBDes juga disertai laporan program kegiatan baik pemerintah pusat, provinsi dan kabupaten yang masuk ke desa"

Hal senada juga sesuai dengan pernyataan Sekretaris Desa.

"Laporan realisasi APBDes juga disampaikan kepada masyarakat desa baampah melalui papan pengumuman desa, hal ini sebagai bentuk pertanggungjawaban pemerintah desa kepada masyarakat desa."

Namun berdasarkan pernyataan Bapak Awung selaku Kepala Seksi Monitoring dan Pengaduan Masyarakat pada DPMD Kabupaten.

"Pemerintah desa memang sudah rutin setiap tahun menyusun Perdes tentang LPJ realisasi pelaksanaan tahun anggaran, namun apabila kita lihat ketentuan bahwa didalam perdes tersebut seharusnya melampirkan laporan program pemerintah baik pusat, provinsi dan kabupaten yang masuk didesa, termasuk pemdes baampah tidak membuat laporan tersebut"

Dari hasil wawancara, observasi dan dokumen yang diperoleh penulis, terkait indikator yang digunakan untuk menganalisis pertanggungjawaban pengelolaan keuangan desa di Desa Baampah terhadap penerapan Peraturan Bupati Nomor 4 Tahun 2019 tentang Pedoman Pengelolaan Keuangan Desa, dapat terlihat bahwa Desa Baampah telah melaksanakan pertanggungjawaban APBDes dengan cukup baik. Namun faktor kurangnya pemahaman aparatur pemerintah desa dalam hal menyusun laporan pertanggungjawaban menyebabkan subtansi isi yang seharusnya masuk dalam laporan pertanggungjawaban keuangan desa tidak sesuai dengan ketentuan.

\section{Pembahasan}

Penulis membahas implementasi pengelolaan keuangan desa dalam hubungannya dengan faktor-faktor implementasi sesuai dengan Teori Edward yaitu struktur organisasi, sumber daya, komunikasi dan disposisi atau perilaku.

Struktur Organisasi, Menurut G. Edward III terdapat dua karakteristik utama dari birokrasi yakni : Standard Operational Procedure (SOP) dan fragmentasi. Dari hasil penelitian dalam hubungan struktur organisasi dengan implementasi pengelolaan keuangan desa diperoleh sebagai berikut :

Faktor pendukung tersebut adalah adanya SOP yang jelas terkait pengangkatan perangkat desa dan juga pelaksana pengelolaan keuangan desa. Sedangkan faktor penghambatnya adalah pembagian kewenangan pengelolaan keuangan desa tidak sesuai ketentuan terutama pengangkatan TPK.

Sumber Daya, Menurut Edward III sumberdaya merupakan hal penting dalam implementasi kebijakan yang baik. Indikator-indikator yang digunakan untuk melihat sejauhmana sumberdaya mempengaruhi implementasi kebijakan terdiri dari : staf; informasi; wewenang; fasilitas.

Faktor pendukung tersebut adalah sebagai berikut :

a. Adanya ketentuan atau informasi formal yang digunakan oleh desa sebagai pedoman pengelolaan keuangan desa.

b. Adanya fasilitas berupa sarana dan prasarana dalam mendukung pelaksanaan kebijakan pengelolaan keuangan desa.

Sedangkan faktor penghambat adalah sebagai berikut :

a. Rendahnya pendidikan penyelenggara pemerintahan desa sehingga berpengaruh terhadap daya pemehaman dan kecakapan dalam melaksanakan pengelolaan keuangan desa.

b. Kurangnya pemahaman Kepala Desa terkait kewenangan dan tanggungjawab yang diberikan sesuai dengan ketentuan pengelolaan keuangan desa. 
Komunikasi, Implementasi yang efektif akan terlaksana, jika para pembuat keputusan mengetahui mengenai apa yang akan mereka kerjakan. Infromasi yang diketahui para pengambil keputusan hanya bisa didapat melalui komunikasi yang baik. Terdapat tiga indikator yang dapat digunakan dalam mengkur keberhasilan variabel komunikasi. Edward III mengemukakan tiga variabel tersebut yaitu : transmisi; kejelasan; dan konsistensi.

Faktor pendukung tersebut adalah adanya transmisi melalui sosialisasi yang dilakukan oleh Tim Kabupaten. Sedangkan faktor penghambat dalam komunikasi adalah:

a. Terjadinya ketidakjelasan informasi dari pembuat kebijakan, unsur pembina, pendamping dan pengawas desa hingga ke pihak pemerintah desa selaku pelaksanan kebijakan.

b. Kurangnya konsistensi informasi yang diberikan oleh pengambil kebijakan sehingga membuat kebingungan bagi pelaksana kebijakan.

Disposisi atau perilaku, Faktor-faktor yang menjadi perhatian Edward III mengenai disposisi dalam implementasi kebijakan terdiri dari : pengangkatan birokrasi; dan insentif.

Faktor pendukung tersebut adalah adanya insentif yang cukup memadai bagi aparat desa. Sedangkan faktor penghambat adalah pengangkatan perangkat desa tidak dilakukan melalui tes atau seleksi namun berdasarkan hubungan kekeluargaan dan kekerabatan sehingga tidak diperoleh perangkat desa yang memiliki tingkat pemahaman dan kecakapan yang baik.

\section{KESIMPULAN}

Implementasi pengelolaan keuangan desa di Desa Baampah Kecamatan Mentaya Hulu berdasarkan Peraturan Bupati Nomor 4 Tahun 2019 tentang Pedoman Pengelolaan Keuangan Desa masih belum berjalan dengan baik dan sesuai dengan ketentuan, sebagaimana diatur dalam $B A B \vee$ Pasal 44 sampai dengan 93.

penulis memberikan saran sebagai berikut :

I. Perlu adanya pembinaan dan pengawasan dengan saling berkoordinasi, komunikasi dan kolaborasi yang lebih baik dari pihak pemerintah kecamatan dan kabupaten (BPKAD, DPMD, Inspektorat) kepada pemerintah desa dalam mengelola anggaran, sebagaimana diatur dalam Perbup No. 4 Tahun 2019 Pasal 95.

2. Perlu adanya peningkatan SDM aparatur pemerintah desa mulai dari Kepala Desa, BPD, Sekretaris Desa dan Bendahara Desa melalui sosialisasi, pelatihan dan pendampingan terhadap pengelolaan keuangan desa sesuai dengan ketentuan Perbup No. 4 Tahun 2019 Pasal 95 ayat (2), (3) dan (4).

3. Penyampaian informasi pagu anggaran desa dari pihak kabupaten agar tidak terlambat sehingga dalam hal penyusunan APBDes tahun berikutnya tidak mengalami keterlambatan kembali.

4. Dalam hal pembinaan dan pengawasan yang lebih optimal terhadap pengelolaan keuangan desa, akan lebih baik laporan pertanggungjawaban keuangan desa yang dilakukan antara bendahara desa dan kepala desa juga dilaporkan ke pihak kecamatan paling lambat tanggal 10 bulan berikutnya, sebagaimana diatur dalam Perbup No. 4 Tahun 2019 Pasal 88.

\section{UCAPAN TERIMA KASIH}

Penulis menyadari sepenuhnya bahwa tulisan ini dapat selesai berkat bantuan, dorongan, bimbingan dan perhatian dari berbagai pihak. Untuk itu pada kesempatan ini penulis mengucapkan terima kasih kepada Rektor, Direktur Program Pascasarjana, Ketua Program Pascasarjana Hukum, Sosial dan Pollitik, Kepala UPBJJ UT Palangka Raya, Dosen Pembimbing I dan 
Muhammad Husni Arifin, S.AG., M.Si.,Ph.D selaku Dosen Pembimbing II yang telah bersedia meluangkan waktu, tenaga dan pikiran untuk memberikan pengarahan dan bimbingan dalam penyusunan tulisan ini. Tidak lupa pula seluruh dosen pengajar tutorial online, staf administrasi dan keluarga besar PPs UPBJJ UT Palangka Raya. Penulis juga mengucapkan terima kasih kepada Kepala Dinas dan Pegawai pada Dinas Pemberdayaan Masyarakat dan Desa Kabupaten Kotawaringin Timur, Camat dan Pegawai Kecamatan Mentaya Hulu, terkhusus Kepala Desa dan Ketua BPD, perangkat desa serta pihak terkait yang telah bersedia menjadi obyek penelitian dalam penyusunan tulisan ini.

\section{REFERENSI}

Abdul Halim, M.Syam Kusufi. (2016). Teori, Konsep dan Aplikasi Akuntansi Sektor Publik. Jakarta : Salemba Empat.

Ahmad Mukhlis Yusuf. (2018). Revolusi Pelayanan Publik. Jakarta : Gramedia Pustaka Utama.

Ahmad Zaini dan Endang Surasetyo Ningsih. (2018). Analisis Proses Penyusunan dan Pelaksanaan APBDesa (Anggaran Pendapatan dan Belanja Desa) Secara Akuntabel, Transparan dan Partisipatig (Studi Pada beberapa Desa di Kota Banda Aceh). Jurnal Ilmiah Mahasiswa Ekonomi Akuntansi (JIMEKA). Vol.3, No.3, EISSN 258I-I002.

Agus Maulana. (2016). Manajemen Strategik. Tangerang Selatan : Universitas Terbuka.

Ar Royan Ramli, dkk. (2018). Ekonomi Desa : Analisis Pemberdayaan Ekonomi Masyarakat Desa. Aceh : Natural Aceh.

Erwan Agus Purwanto,dkk. (20/5). Implementasi Kebijakan Publik Konsep dan Aplikasinya Di Indonesia. Yogyakarta : Gava Media.

I Wayan Purwa A. dan I Gusti Ayu Nyoman Budiasih. (2019). Realitas Implementasi Pengelolaan Keuangan Desa pada APBDes di Desa Dauh Pekan. Di Unduh I Juli 2019, dari situs World Wide Web :

https://ojs.unud.ac.id/index.php/jiab/user/profile

Kecamatan Mentaya Hulu dalam Angka Tahun 2020.
Muchlis Hamdi. (20I4). Metodologi Penelitian Administrasi. Tangerang Selatan : Universitas Terbuka.

Muhadam Labolo. (20I5). Dinamika Politik dan Pemerintahan Lokal. Bogor : Ghalia Indonesia.

Muhammad Ismail, Ari Kuncara Widagdo, Agus Widodo. (2016). Sistem Akuntansi Pengelolaan Dana Desa. Jurnal Ekonomi dan Bisnis. Vol. 19 No. 2, ISSN 1979 - 647I.

Pasolong Harbani. (20/3). Metode Penelitian Administrasi Publik. Bandung : Alfabeta.

Sandu Siyono, Ali Sodik. (20I5). Dasar Metodologi Penelitian. Yogyakarta : Literasi Media Publishing.

Subando Agus Margono. (20I5). Manajemen Publik Kontemporer. Yogyakarta : Gava Media.

Sugiyono. (20I3). Metodologi Penelitian Kuantitatif, Kualitatif dan R\&D. Bandung : Alfabeta.

Suwartono. (2014). Dasar-dasar Metodologi Penelitian. Yogyakarta : Andi Offset.

Wahjudin Sumpeno. (20II). Perencanaan Desa Terpadu. Banda Aceh : Read.

Wijaya, HAW. (20I2). Otonomi Desa Merupakan Otonomi Yang Asli, Bulat dan Utuh. Jakarta : Rajagrafindo Persada.

Yeremias T. Keban. (20I4). Enam Dimensi Strategis Administrasi Publik. Yogyakarta : Gava Media.

Yusuf A. Muri. (20I4). Metode Penelitian : Kuantitatif, Kualitatif, dan Penelitian Gabungan. Jakarta : Prenadamedia.

https://kertyawitaradya.wordpress.com/2010/01/26/tinj auan-teoritis-implementasi-kebijakan-modelc-g-edward-iii/

https://www.keuangandesa.info/20I5/ I I/pelaporandan-pertanggungjawaban.html 